\title{
INVESTIGATING THE IMPLICATION OF BIG DATA ANALYTICS ON CONSUMER FINANCE IN CHINA
}

\author{
Prof. Jiwat Ram ${ }^{1}$, Ding Ronggui ${ }^{1}$ and Hong Yang ${ }^{2}$ \\ ${ }^{1}$ School of Management, Shandong University, Jinan, China \\ ${ }^{2}$ IBSS, XJTLU, China
}

\begin{abstract}
The use of Big Data analytics for business improvements is a vital strategy for survival. In this paper, we report a study that investigates the role of $B D$ analytics on consumer finance, credit card finance in China-a research area that has largely remained unexplored. The largeness and diversity of Chinese consumer market merit an urgent attention and understanding of role of BD analytics is significant both theoretically and managerially. This study achieves that target. Given the exploratory nature of study, we take a qualitative approach. We conduct approximately 30 interviews with baking and finance sector respondents. The data will be recorded, transcribed and translated. We will analyze data using content analysis / thematic analysis technique.
\end{abstract}

\section{KEYWORDS}

Consumer finance; Credit Card finance; Business analytics China

\section{INTRODUCTION}

Big data is another name of large set of massive data that are useful but challenging to process using traditional means (Crosman 2012). Big data analytics refers to the process of extracting useful business information through a combination of software tools and algorithms. With the development of advanced technology, the threshold of processing data has become blur allowing organizations to use a variety of approaches to handle and analyze unstructured and semistructured data (Kugel 2013). It is estimated that there are 1.35 billion customers and 618 million Internet users in China, and the value of China's information data market could be over 3.2 trillion yuan in 2015 (Yao, 2014).

Consumer finance, which refers to short-term loans for personal consumption of durable goods or services has become a promising industry in China (Li 2012). According to Przzom (2012), during 2007 to 2011 period the compound annual growth rate (CAGR) of consumer finance market in China was $28.33 \%$ perhaps due to expanded domestic demand for consumer products. Thus, the development of domestic demand in China could enhance the opportunity for consumer finance market, especially for lending activities, to develop.

Credit card loan is increasingly becoming popular in consumer finance market in China, because of high profit and growth rate. Resultantly banking sector is concentrating heavily on credit card offerings to enhance business performance (Hughes 2016). Although banks in China are eager to

Natarajan Meghanathan et al. (Eds) : ACSIT, SIPM, FCST, CoNeCo, CMIT - 2017

pp. 129- 135, 2017. @ CS \& IT-CSCP 2017

DOI : $10.5121 /$ csit.2017.70810 
collect consumers information to produce tailored products, the lack of reliable consumer credit evaluation and risk management abilities could be an obstacle for further developments of banking sector (China Daily 2004, 2015).

Big data analytics could help banking sector to build and offer innovate financial products and services that meet consumer needs, help improve management of risks of default, make better decisions, and thus enhance business performance (McMalcolm 2015, Manyika et al. 2011, Kambatla et al. 2014, Spotfire Blogging Team 2013). Despite usefulness of BD analytics existing research on the advantages of big data for improvements in consumer finance is in its infancy and practical applications of big data analytics for enhancements in credit card offerings in China remain largely unknown. While some research highlight the performance of commercial banks in using big data analytics, specific research on the operation and use of big data analytics for credit card offerings merit further attention. This research, therefore, fills the gap in knowledge by investigating the implications of big data analytics on consumer finance especially for credit card offerings in China. The research question is:

What are the implications of big data analytics on consumer finance in banking sector such as credit card offerings?

This research is significant in not only investigating an issue in a largely unexplored research strand but also in providing an understanding to managers on how BD analytics can help in developing solutions in consumer finance segment with tailored credit card offerings. The research will be able to build knowledge on how could banking sector differentiate among various consumer groups and gather right consumer data, ensure security of consumers' information, cope with the analytics skill deficiencies and make rational decisions. The results can be used for making long-term strategies for credit card offerings and improvements in business performances with enlarged product portfolios and revenues.

\section{RELATED WORK}

\subsection{Consumer Finance in China}

Consumer finance refers to personal lending activities of durable goods and services, including credit cards, mortgage, and automotive finance (Li 2012). Although consumer finance with low current penetration in China shows a lack of development compared to developed countries, but with a large population combined with urbanization activities consumer finance industry in China is promising industry. As Chinese government is planning to shift GDP growth focus from exports to domestic consumption, consumer lending will become a significant sector (Li 2012).

\subsection{Credit Card offerings in banking sector in China}

Credit card loans are becoming increasingly popular among Chinese with 15.2 trillion yuan credit card payments by 2014 and high volume growth (China Daily, 2015). Credit card loan is a fastgrowing type of loan in consumer finance, with the low initial base, which also implies that this classification of loan will show its potential to grow in the future (Przoom 2012).

Hughes (2016) highlighted the importance by suggesting that credit card loan is a highly profitable project for banks and one way to build loyal credit card customers is to establish strong relationship with consumers assisted by big data analysis. To provide tailored services to customers, to increase credit card holders' portfolio and increase the consumption by cardholders, banks are eager to analyse target consumers' preferences and creditworthiness. However, as China's consumer credit evaluation system and analytics ability is still very nascent and not well- 
developed, banks lack the ability to track records of the financial products they offered to customers, banks might lend too much money to those who have weak creditworthiness (China Daily 2004). In addition, according to a report of China Daily (2015), the rising risks of delay repayment for more than half a year is 42 percent, thus banking sector needs to consider the risk management in credit card loans.

As consumer finance companies and Internet-based financial institutions, the non-banking institutions, fiercely compete to capture the market share, banks should find an efficient approach to enhance businesses performance to maintain market share. In this context, banks have already deployed various strategies such as offering discount on travel routes, offering cash rebates, providing discount on flights, hotel bookings and car rentals, providing various kinds of special treatment to customers, and creating online channels to attract potential customers who own mobile phones (Jiang 2016).

\subsection{Role of Big Data Analytics on Consumer Finance}

According to Kambatla et al. (2014), if a retailer could fully leverage the potential of big data analytics, it could increase its operation margin by at least 60 percent. Big data analytics enables businesses to access and analyze multiple data sources with rapid speed, improve decision making, develop tailored services that meet consumer needs, and obtain better judgement of lending activities thus minimizing losses (McMalcolm 2015).

Using big data analysis could assist banking sector to obtain competitive advantage in many ways. First, it could provide tools and methods for banks to access data and perform analytics in minimum amount of time and easy processes (Manyika et al. 2011). Second, big data analytics could enhance the predictive accuracy of future business plan outcomes by using historical data (Groenfeldt nd). Third, big data analytics allows banks to innovate tailored products that could meet the changing requirements of customers through understanding of specifics of customer behaviours and patterns (Manyika et al. 2011). Fourth, as the market and consumer behaviors involve many uncertainties, banks could use big data analytics to track consumer transactional behaviors and manage risks of default (Spotfire Blogging Team 2013; Fang \& Zhang, 2016). Finally, BD analytics can help banking sector to save cost of tracking and monitoring consumers' information and reduce potential losses from defaulting (Kshetri, 2016).

Particularly with the help of big data analytics, banking sector is able to transform the semistructured and un-structured data into structured data using algorithms and then analyse for business performance improvements (Marr 2016). Banks generate data through multiple channels, such as offline consumption and online transactions (Sen 2014). In this way, banks are able to segment data and track typical customers' financial transaction behaviors across various segmentations to provide personalized services, and build and maintain loyal customer base (Bagchi 2014).

Moreover, a 2010 global fraud study showed that banking and financial services industry dealt with more than 16 percent of fraudulent transactions, thus fraud detection is vital to banking sector development. With advanced BD analytics, banks could scan historical records of consumers to identify abnormal variabilities and even could predict the default risk of consumers, and thus manage market uncertainties and control exposure risk (Pramanick 2013, Marr 2016; Groll et al., 2015).

Despite its advantages, big data analytics also faces many challenges, for instance, choosing the right data sources, the safety of data storage and the gaps in skill for big data analytics (Elan financial services nd, Bagchi 2014). 


\subsection{Big Data implications on Credit Card offerings in China}

Commercial banks, as the leaders of credit market, especially CITIC bank and ICBC (Industrial and Commercial banks of China) in China have pursuing opportunities to building close relationship with consumers. CITIC bank uses SAS (statistical analysis system) and Pivotal Greenplum Database to establish open-platform and improve business performance (Pivotal nd). With the help of advanced data system, CITIC bank is able to provide improve productivity through a customer contact center, maximize marketing campaigns, accelerate data analytics speed and avoid risks. In addition, although ICBC has developed e-payment and online financing system and managed over 100 billion yuan transactions through their e-commerce platform, it is significant for ICBC to use big data analytics to offer suitable financial services (Jiang 2015).

Though banks in China are recognizing the benefits generated from big data applications and are trying to harness the potential, there is still little research that provides specific explanation of how big data analytics is used in credit card offerings for consumer finance in China.

To sum up, based on an extensive review of the literature it could be concluded that the implication of big data on consumer finance such as credit card offerings has not been researched, not just in global banking context but also in Chinese context. Banking and finance is considered vital to economy and society and consumer finance plays a significant role in banking operations, meriting further investigations. Given the gap, we investigate the role and implications of BD analytics on consumer finance through credit card offering from a Chinese perspective.

\section{METHODOLOGY}

Given the exploratory nature of research, we will take a qualitative approach to the study. The research process is divided into three parts - questionnaire design, data collection and data analysis. We will conduct an extensive literature to identify key issues related to credit card finance and construct a semi-structured questionnaire to seek respondents opinions on how BD analytics can help improve the identified issues. Such an approach will help us understand the implications in areas such as classification of consumer groups, approaches that banks could take to analyze transaction data, techniques of using big data analytics to obtain consumers' preference and predict potential risk, the processes that banks use to develop credit card offering strategies. The study will conduct an approximately 30 interviews with target respondents form a variety of occupational backgrounds such as commercial banks' senior managers and financial service industry experts in China. We will use both, online system such as Sojump, or hand-delivered methods to conduct interviews, either face-to-face or by online software (e.g. Skype or WeChat). Interviews will be recorded with respondents' permission, and transcribed. Because the majority of target respondents are Chinese, researcher will translate the Chinese data into English version.

We will analyse the data using Nvivo 10 and content analysis methods. It will enable us to analyze information from interviews, notes of observations with less time and high quality (Hilal and Alabri 2013).

\section{Authors' CONTRIBUtions}

Authors contribute through this study to extend knowledge for both theory and practice in unique ways. Theoretically, the study build fundamental and basic knowledge on the implications of Big Data analytics on consumer finance which is largely unexplored. The theoretical knowledge gained by this study can be used for doing a cross-sectional study to generalize the findings.

The study will also help lay foundation for study of BD analytics in other directions in the banking and finance sector. 
Managerially, the study is an important milestone in providing knowledge on how BD analytics can be used for implementation of credit card based financing in China. The results can be used for driving strategies and plan of action for setting the scene of credit card based innovation offerings. China is a large market and with growing urbanization trends, more and more people will choose credit card based finance. Hence understanding how BD analytics can help in growth of consumer portfolio is important and hence the significance of the study.

\section{LIMITATIONS}

Being the exploratory study, we will be only accessing a small number of respondents. So generalization of results shall be done with caution.

Another limitation is that the limited availability of experts could influence the outcome of the study and generalisation of results. Since most of the respondents will be Chinese so communication and translation of data from Chinese to English language could also entail some limitations.

\section{EXPECTED OUTCOMES}

We expect to establish how BD analytics could be used for improving decision making processes in relation to consumer finance product offerings. The study will focus on understanding the characteristics of products, their features and benefits, ease of use, after sales services and cost of using the products. The results are expected to show the implications for both product / service providers and consumers, thus identifying areas that have synergies and how to exploit those synergies.

The questionnaire will include questions on issues involving how Big Data analytics will help in developing new credit card products, new distribution channels, developing strategies for improving credit card offerings.

\section{CONCLuSion}

While big data analytics may lead to competitive pressure to financial institutions, it also offers opportunities to enhance business performance and expand the efficiency of product / service offerings. Big data implications on consumer finance is expected to be beneficial to financial institutions in improving the relationship between consumers and card issuers, avoiding potential risk of overdue payment, developing innovating products, increasing work efficiency and expanding business scales. Banks in China are more likely to leverage upon the opportunities of big data analytics in establishing online consumer centers and developing insights on consumer behaviors thus improve business administration and long-term credit card supply strategies. This study therefore contributes to enrich our knowledge on big data implication on consumer finance especially for credit card offerings in China

\section{REFERENCES}

[1] Bagchi, S. (2014). Data analytics to play a key role in banks' growth. Available at http://www.cxotoday.com/story/data-analytics-to-play-a-key-role-in-banks-growth/ [Accessed 12 Nov. 2016].

[2] China Daily. (2004). Banks target nation's lucrative consumer finance market. Available at http://www.china.org.cn/english/BAT/90357.htm [Accessed 7 Nov. 2016]. 
[3] China Daily. (2015). China credit card transactions hit 15.2t yuan in 2014. Available at http://www.chinadaily.com.cn/business/2015-07/29/content_21440258.htm [Accessed 7 Nov. 2016].

[4] Crosman, P. (2012). 9 Big data challenges banks face. Available at http://www.americanbanker.com/issues/177_157/nine-big-data-challenges-banks-face-10518181.html [Accessed 7 Nov. 2016].

[5] Elan Financial Services. (nd). Developing a credit card strategy leveraging big data. Available at http://www.creditunions.com/articles/developing-a-credit-card-strategy-leveraging-bigdata/\#ixzz4OSRY2Ggw [Accessed 7 Nov. 2016].

[6] Fang, B., \& Zhang, P. (2016). Big Data in Finance. In Big Data Concepts, Theories, and Applications (pp. 391-412). Springer International Publishing.

[7] Gascon, D. (2015). Getting the most out of big data. Available at http://www.computerworld.com/article/2912441/big-data/getting-the-most-out-of-bigdata.html?nsdr=true\#tk.ctw-infsb [Accessed 7 Nov. 2016].

[8] Goernfedlt, T. (nd). Big data in finance can improve retention and returns. Available at https:/insights.samsung.com/2016/03/28/big-data-in-finance-can-improve-retention-and-returns/ [Accessed 7 Nov. 2016].

[9] Groll, T., O'Halloran, S., Maskey, S., McAllister, G., \& Park, D. (2015). Big Data and the regulation of banking and financial services. Bank Financial Services Policy Report, 34(12), 1-10.

[10] Hilal, A. H. and Alabri, S. S. (2013). Using Nvivo for data analysis in qualitative research. International interdisciplinary journal of education. Vol. 2, No. 2, pp. 181-186.

[11] Hughes, A. M. (2016). How to retain credit card customers. Available at http://www.dbmarketing.com/articles/Art175.htm [Accessed 7 Nov. 2016].

[12] Jiang, X. (2015). ICBC to accelerate internet strategy. Available at http://www.chinadaily.com.cn/business/2015-03/25/content_19909019.htm [Accessed 16 Nov. 2016].

[13] Jiang, X. (2016). Banks fight back in the consumer finance market. Available at http://www.chinadaily.com.cn/bizchina/2016-09/26/content_26892306.htm [Accessed 7 Nov. 2016].

[14] Kambatla, K., Kollias, G., Kurma, V. and Grama, A. (2014). Trends in big data analytics. Journal of parallel and distributed computing. Vol. 74, No. 7, pp. 2561-2573.

[15] Keshetri, N. (2016). Big data's role in expanding access to financial services in China. International journal of information management. Vol. 36, No. 3, pp. 297-308.

[16] Kugel, R. (2013). Finance can get a big advantage from big data. Available at http://www.smartdatacollective.com/robert-kugel/168071/finance-can-get-big-advantage-big-data [Accessed 7 Nov. 2016].

[17] $\mathrm{Li}, \mathrm{J}$. (2012). Consumer finance set to boom in China. Available at http://www.chinadaily.com.cn/business/2012-09/12/content_15751947.htm [Accessed 7 Nov. 2016].

[18] Manyika, J., Chui, M., Brown, B., Bughin, J., Dobbs, R., Roxburgh, C. and Byers, A.H. (2011). Big data: The next frontier for innovation, competition and productivity. Available at http://www.mckinsey.com/business-functions/digital-mckinsey/our-insights/big-data-the-nextfrontier-for-innovation [Accessed 7 Nov. 2016]. 
[19] Marr, B. (2016). Big data in banking: How Citibank delivers real business benefits with its data-first approach. Available at http://www.forbes.com/sites/bernardmarr/2016/09/09/big-data-in-bankinghow-citibank-delivers-real-business-benefits-with-their-data-first-approach/3/\#220f798c13ca [Accessed 12 Nov. 2016].

[20] McMalcolm, J. (2015). Is big data helping improve consumer finance? Available at http://blog.ideacafe.com/big-data-helping-improve-consumer-finance [Accessed 7 Nov. 2016].

[21] Oracle. (2016). An enterprise architect's guide to big data. Available at

[22] http://www.oracle.com/technetwork/topics/entarch/articles/oea-big-data-guide-1522052.pdf [Accessed 7 Nov. 2016].

[23] Pivotal. (nd). China CITIC bank driving revenue and reducing risk. Available at https://pivotal.io/big-data/case-study/china-citic-bank-driving-revenue-and-reducing-risk [Accessed 7 Nov. 2016].

[24] Pramanick, S. (2013). Analytics in banking services. Available at http://www.ibmbigdatahub.com/blog/analytics-banking-services [Accessed 12 Nov. 2016].

[25] Przoom. (2012). BRIC data Publishes Emerging Opportunities in the Chinese Consumer Finance Market. Available at http://www.przoom.com/news/114563/ [Accessed 7 Nov. 2016].

[26] Rouse, M. (2014). Big data analytics. Available at http://searchbusinessanalytics.techtarget.com/definition/big-data-analytics [Accessed 7 Nov. 2016].

[27] Sen, A. (2014). Banking on big data analytics. Available at http://www.livemint.com/Industry/F5uNVbogJfsNB7cSt1 toBL/Banking-on-Big-Data-analytics.html [Accessed 12 Nov. 2016].

[28] Spotfire Blogging Team. (2013). Big data analytics to mitigate risk in banking, insurance. Available at http://www.tibco.com/blog/?p=20587\&utm_source=tuicool\&utm_medium=referral [Accessed 7 Nov. 2016].

[29] Yao, M. (2014). Big opportunities in China to mine big data. Available at http://www.shanghaidaily.com/feature/news-feature/Big-opportunities-in-China-to-mine-bigdata/shdaily.shtml [Accessed 7 Nov. 2016] 